\title{
Digital Mapping of Soil Associations and Eroded Soils (Prokhorovskii District, Belgorod Oblast)
}

\author{
A. P. Zhidkin ${ }^{a, ~ *, ~ M . ~ A . ~ S m i r n o v a ~}{ }^{a, b}$, A. N. Gennadiev ${ }^{b}$, S. V. Lukin ${ }^{c}$, \\ Ye. A. Zazdravnykh ${ }^{d}$, and N. I. Lozbenev ${ }^{a}$ \\ ${ }^{a}$ Dokuchaev Soil Science Institute, per. Pyzhevskii 7, Moscow, 119017 Russia \\ ${ }^{b}$ Lomonosov Moscow State University, Leninskie Gory 1, Moscow, 119999 Russia \\ ${ }^{c}$ Belgorod State University, ul. Pobedy 85, Belgorod, 308015 Russia. \\ ${ }^{d}$ Belgorod Agrarian Center, ul. Shchorsa 8, Belgorod, 308027 Russia \\ *e-mail: gidkin@mail.ru
}

Received April 19, 2020; revised May 24, 2020; accepted June 17, 2020

\begin{abstract}
A new method of digital mapping of the soil cover pattern with calculation of the share of soils of different taxa and degree classes for soil erosion in the soil associations is proposed. A comparative analysis of soil maps obtained using different methods of construction (visual expert and digital) and with their different contents (displaying the dominant soil or soil associations) has been performed. In the case of mapping by the visual expert method (with the display of the dominant soil), a significant underestimation of the total area of moderately and strongly eroded soils in comparison with the digital mapping is noted. These differences are due to the underestimation of the area of small polygons with moderately and strongly eroded soils in the composition of soil associations on slopes of low steepness and in shallow hollows in the visual expert method of mapping. When the content of digital maps is generalized from soil associations to dominant soil categories, a significant change in information on the degree of soil degradation by erosion is also noted. Comparison of visual expert and digital methods for mapping soils of different taxa indicates a high degree of compliance between the spatial location and area of soil delineations with similar component content in both cases. The greatest differences between the soil maps created by these methods are noted for the soils with periodic overmoistening, namely, meadow-chernozemic (Luvic Chernic Phaeozem (Oxyaquic)) and chernozemic-meadow (Luvic Stagnic Chernic Phaeozem) soils because of the poor consideration for microtopography in traditional mapping. In general, it can be concluded that the creation of a digital map is more difficult in terms of the need to use specialized computer programs and mathematical models. However, the resulting digital databases contain information of a higher level of detail than traditional soil maps.
\end{abstract}

Keywords: WATEM/SEDEM, chernozem, agricultural landscape, soil association, soil cover pattern

DOI: $10.1134 / \mathrm{S} 1064229321010154$

\section{INTRODUCTION}

One of the key directions in the study of soil geography is the development of methods for the creation and verification of spatial models of soil cover patterns presented in the form of soil maps. Large-scale mapping of the soil cover in Russia today is mainly performed on the basis of a visual expert method with the identification of the areas of prevailing (dominant) soils of various taxa. The quality and accuracy of the maps constructed on the basis of this method in largescale mapping are largely determined by the accuracy of the field study of the soil cover and qualification of the soil cartographer.

A more detailed representation of soil cover on the maps is associated with the depiction of soil combinations. This approach is based on the theory of the soil cover pattern of Fridland [21]. The use of soil combinations as an object of mapping makes it possible to better reflect the real features of the soil cover pattern. As a rule, mapping of soil combinations requires much more serious field studies than mapping of dominant soils [12]. The active large-scale soil mapping of farmland in Russia took place in the 1970s-1980s. Detailed soil surveys with a dense network of sampling were performed. Unfortunately, under modern conditions, large-scale mapping of soil combinations in Russia is greatly reduced and is implemented only in local areas within the framework of research projects of individual scientific groups $[1-3,19,23,24,30]$. In some cases, the soil cover is mapped with representation of not only the dominant soil but also the accompanying soils and soil inclusions. In the United States, such mapping units are called soil associations [26]. Below in this work, the term soil association (SA) will be used, which is understood as the totality of soil taxa in the given delineation with due account for their share. 
When mapping soils of agricultural landscapes, special attention is paid to the soil erosion. This indicator is one of the main criteria for agroecological grouping of lands [5]. On the basis of the maps of soil erosion, measures are developed to increase soil fertility, and the boundaries of lands suitable or not recommended for plowing are determined. The traditional method of visual expert mapping of soil erosion has a number of disadvantages. The identification of the boundaries of the areas of eroded soils is carried out on the basis of the assumption about direct relationship between the steepness of slopes and the degree classes for soil erosion [13]. At the same time, it is notorious that, in addition to the steepness of slopes, soil erosion is affected by other parameters of the topography, in particular the length, exposure, and shape of the longitudinal and transverse profiles of slopes [7]. The assumption of a direct relationship between the steepness of slopes and the degree classes for soil erosion is a forced measure, since it is difficult to assess all morphometric parameters of the topography and their complex impact on erosion-accumulative processes with a visual expert method of mapping. As a result, this method of mapping leads to inaccuracies.

Mapping of the eroded soils, as well as mapping of soil taxa, is carried out mainly on the basis of taking into account the dominant category. At the same time, detailed studies on the key plots [18, 21] indicate that the areas of eroded soils on slopes of low steepness have a small area and are fragmentarily interspersed into the areas of noneroded soils. On plowed slopes of high steepness, the share of eroded soils increases, their dominance is noted, which, as a rule, does not lead to a continuous (one hundred percent) distribution of strongly eroded soils. As a result of taking into account the dominant degree of erosion class during soil mapping, there is a significant underestimation of the eroded soils areas in the upper and middle parts of slopes, where noneroded soils predominate; whereas the areas of strongly eroded soils in the lower parts of slopes are overestimated. These drawbacks of the traditional method of visual expert mapping of soil erosion indicate the need for the development of new approaches that contribute to the refinement of cartographic information about eroded soils.

State-of-the-art advances in the development of GIS technologies and modeling of soil-landscape relations and erosion processes make it possible to develop approaches to large-scale mapping of the soil cover at a new technological level. In particular, the methods of digital soil mapping based on the search and mathematical expression of relationships between soils and soil forming factors allow the construction of large-scale soil maps of increased accuracy even with a smaller number of soil pits on the investigated territory in comparison with the visual expert method [27, 32]. Thus, available studies [30, 33] demonstrate the fundamental possibility of creating maps of dominant soils and soil associations by the digital method.
Approaches to digital mapping of associations of differently eroded soils on the basis of combined use of field soil survey data and mathematical erosion modeling were first described in [6].

An important technical advantage of digital soil maps in comparison with traditional soil maps is the possibility to store information of almost unlimited volume and of any kind. In this case, the level of detail of information about the soil cover depends not on the scale of the map, as in the case of a paper medium, but on the level of detail of digital soil mapping determined by the accuracy and detail of the initial input parameters [15].

The aim of this study was to develop approaches to digital soil mapping based on the creation of a spatial soil cover model indicating the proportion of soils of different taxa and the degree of erosion for high-resolution regular grid for arable land in Prokhorovskii district of Belgorod oblast. Also, the issues of the work included the comparison of the results of digital and visual expert methods of soil mapping.

\section{STUDY OBJECTS}

Prokhorovskii district of Belgorod oblast is located in the southeastern part of the Central Russian Upland. The climate is moderately continental with hot summers and relatively cold winters; the humidity coefficient (precipitation to potential evaporation ratio) is 1.0. The mean January temperature is $-6.8^{\circ} \mathrm{C}$, and the mean June temperature is $19.3^{\circ} \mathrm{C}$; the mean annual temperature is $6.6^{\circ} \mathrm{C}$. Annual precipitation varies widely (from 350 to $700 \mathrm{~mm}$ ) with the mean value of $558 \mathrm{~mm}$ [11].

The studied territory represents an undulating plain with absolute heights varying from 165 to $267 \mathrm{~m}$ a.s.l. and a general slope to the south (Fig. 1). The degree of topography dissection and slope steepness increase in the southward direction. In the western part of the key site, there are plateau-like interfluves with gentle (less than $2^{\circ}$, rarely $3^{\circ}-5^{\circ}$ ) slopes dissected by a network of balkas (flat-bottomed ravines) of medium density. In the eastern part of the plot, there are arching watersheds, well-developed river valleys, branched and short circus-like balkas, numerous hollows, and karst sinkholes. Smooth slightly sloping watershed surfaces predominate. The soil-forming rocks are loose sediments of light loamy to medium clayey textures, mainly silty. In the southeastern and central parts of the key site, pre-Quaternary saline clays outcrop to the surface in some places and may serve as parent rocks. On steep slopes, chalk stones may occur close to the surface. The age of agricultural development of the study area, on average, does not exceed 200 years [25]. Typical crop rotations include grain crops (spring barley and winter wheat predominate), row crops (corn and sugar beet predominate), and perennial herbs [4]. 


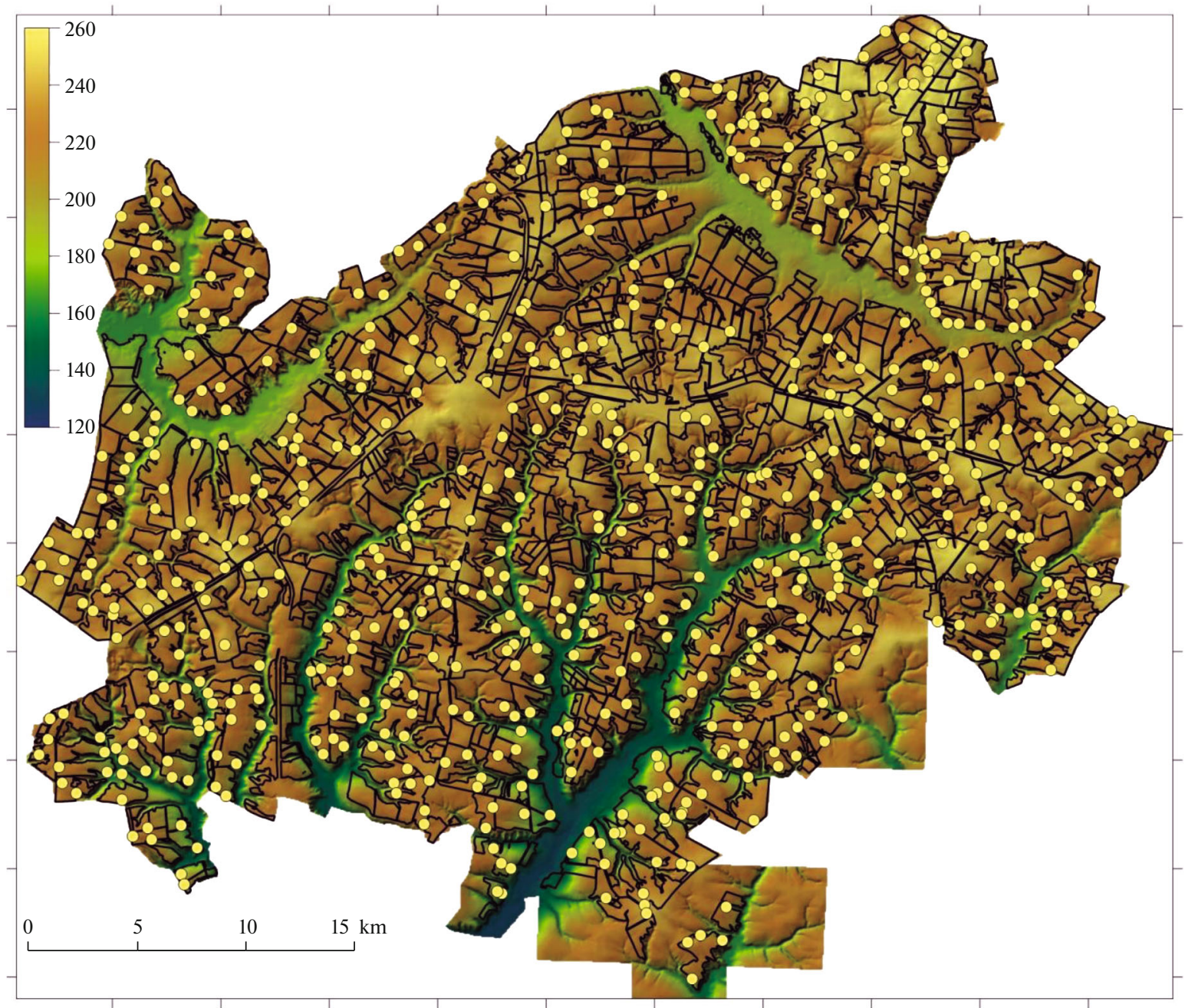

Fig. 1. The topography of the study area and location of soil sampling points.

\section{MATERIALS AND METHODS}

The work is based on data on the morphology of 639 soil profiles and a detailed digital elevation model. These materials, as well as the soil-erosion map created by the traditional (visual expert) method of largescale soil mapping, were obtained from the Federal State Budgetary Institution "Belgorodsky Center for Agrochemical Service.” The points of field sampling were studied within the framework of the third round of field soil survey (2016-2017) of arable land in Prokhorovskii district.

The cell size of the digital elevation model and all other materials used for the creation of digital maps and the maps themselves is $20 \times 20 \mathrm{~m}$. The choice of this cell size was based on the recommended parameters for the WaTEM/SEDEM v. 2004 erosion model used in this work $[38,39]$. The processing of the provided data was carried out in SAGA GIS, Grass GIS, and Statistica software.
The creation of the SA map was carried out on the basis of the use of two independent digital models, one of which was aimed at mapping SAs of soil taxa, while the second model was aimed at mapping SAs with different degree classes for soil erosion. The resulting digital map of SAs was compiled by superimposing polygons from the maps of showing the participation of different soil taxa and soils of different degrees of erosion in each element of the regular grid (pixel). If the area of a given delineation was less than $0.1 \%$ of the entire mapped area, this delineation was combined with SA of a close component composition.

Creation of the map of soil associations based on the model of soil-landscape relationships. Creation of soil maps includes two stages: (1) search for factor-indicative characteristics (predictors) that are most informative in identifying the spatial heterogeneity of the soil cover and (2) interpolation of point data obtained during field studies over the entire study area. In the case of digital soil mapping, both of these stages are 
implemented by formalized methods. In this study, the method of linear discriminant analysis with a stepwise selection of predictors was used. The development of this method and demonstration of the results of its application for mapping soil cover patterns are presented in [19, 29, 31]. On one hand, this method makes it possible to identify linear combinations of factors to discriminate between different soil taxa in the space of soil forming factors in the best way; on the other hand, it predicts the probability of occurrence for a given soil taxon under given combinations of soil forming factors at each point of the studied area. The morphometric characteristics of the topography and climatic parameters calculated for each cell of the regular grid on the entire arable land of Prokhorovskii district were used as factor-indicator characteristics (quantitative parameters of soil forming factors). Morphometric parameters of the topography (slope steepness; depth of closed depressions; transverse, plan, and total curvature; total and modified catchment area; topographic wetness index; slope length and slope index (LS factor); elevation above the base of erosion; topography roughness index (TRI); and topographic position index (TPI $250 \mathrm{~m}, 500 \mathrm{~m}, 1000 \mathrm{~m}$ and further up to $4000 \mathrm{~m}$ with a step of $500 \mathrm{~m}$ ) were calculated in the SAGA GIS program using the spatial analysis module. Climatic parameters included the total potential annual solar radiation entering the pixel surface and the total redistributed precipitation layer calculated using the SIMWE model.

Linear discriminant analysis revealed the following leading factors of the spatial differentiation of soils: the value of the redistributed precipitation layer, elevation over the base of erosion, slope steepness, and TPI $4000 \mathrm{~m}$. The values of the redistributed precipitation layer obtained in the SIMWE model made it possible to determine the spatial position of overmoistened (meadow-chernozemic (Mch), Luvic Stagnic Chernic Phaeozems) and chernozemicmeadow (CHm), Luvic Stagnic Chernic Phaeozems)) soils; the combination of TPI $4000 \mathrm{~m}$ and elevation above the base of erosion determined the position of typical (CHt), Haplic Chernozems) and leached chernozems $(\mathrm{CHl})$, Luvic Chernozems and Luvic Chernic Phaeozems) at certain heights of the watershed slopes and interfluves. The steepness of the slopes made it possible to map the localization of typical calcareous chernozems ( with effervescence in the humus horizon) (CHtk), Haplic Chernozems and Calcic Chernozems) on gentle slopes. As a result, the probabilities of occurrence for each soil unit in cells of the regular grid for arable land of Prokhorovskii district were estimated. These probabilities were interpreted as the share of a pixel occupied by the predicted soil [19].

It was found that the spatial position of some soils depends on the character of material and the history of land use rather than on the parameters of topography and climate used as predictors in the constructed model of soil-landscape relations. In particular, resid- ual-calcareous Chernozems (CHrk), Haplic Chernozems and Calcaric Phaeozems) are formed, when hard calcareous rocks occur close to the surface; Solonetzic chernozems (CHsn), Protosodic Chernozems and Sodic Chernozems) are confined to the outcrops of pre-Quaternary saline clays; podzolized chernozems (CHp), Luvic Greyzemic Chernic Phaeozems) and dark gray soils (DG), Luvic Greyzemic Chernic Phaeozems) are confined to old-age forest areas, deforested in recent times. According to the traditional map, all these soils occupy only about $3 \%$ of the study area. Owing to the low predictive power of the model for these soils and the lack of cartographic data on the distribution of close to the surface hard calcareous rocks and saline sediments, as well as data on the history of land use, which could be used to improve the model, it was decided to use information on the distribution of these soils from a traditional soil map. In the areas, where these soils are widespread, new SAs were identified. CHrk, CHsn, CHp, DG were added to SAs as dominant soils. Thus, four new groups appeared on the map of SAs: leached solonetzic chernozems and typical solonetzic chernozems (CHlcnCHtsn); typical solonetzic chernozems and leached solonetzic chernozems (CHtsnCHlsn); residual-calcareous chernozems and typical calcareous chernozems ( $\mathrm{CHrkCHtk})$; and dark gray soils, podzolized chernozems, and leached chernozems (DGCHpCHl).

The soil area in a pixel was calculated by multiplying the soil fraction from the pixel area by the pixel area $\left(400 \mathrm{~m}^{2}\right)$; areas of the same soils in different pixels were summed up. The created database in the form of a table of information on the proportion of soils of different taxa in each pixel can be used for practical or scientific purposes without distorting the level of detail. However, visual display of this information in the form of a map is impossible without its generalization and, as a consequence, generalization and loss of some information.

For the purpose of visualization of the resulting digital database in the form of a map (Fig. 2), the rules for assigning a pixel to the corresponding SA were used in accordance with the guidelines for constructing maps for the forest-steppe zone [17] (Table 1). The criteria for identifying SAs are based on the proportion of soils in each pixel, since in digital soil mapping, regular grid elements (pixels) serve as intermediaries between point data and factor bases [19]. Note that the content of individual pixels or small groups of pixels does not give an idea of the soil cover pattern and the composition of SAs. Only the entire set of pixels (1.8 million pixels are analyzed in this study) makes it possible to judge the composition, spatial position, and configuration of SAs. Single pixels on the map have been removed by filtering.

Mapping of soil associations with different shares of degree classes for soil erosion was performed via comparing the rates of soil erosion calculated for each pixel 



Fig. 2. Soil maps of arable territories: (a) traditional map displaying dominant soil categories and (b) digital map displaying soil associations.

using an erosion model and the degree classes for soil erosion diagnosed during the field survey [6]. The WaTEM / SEDEM v. 2004 model was used to calculate the erosion rate [38, 39]. The rainfall erosivity index $\left(R_{30}\right)$ was taken from the raster map "Global Rainfall Erosivity" [35]. For Prokhorovskii district, its values vary from 270 to $320 \mathrm{MJ} \mathrm{mm} /($ ha $\mathrm{h}$ ). The index of soil loss tolerance determined by the soil texture and 
Table 1. Criteria for identifying soil associations based on the share of soils of different taxa in a pixel [17]

\begin{tabular}{|c|c|c|c|c|}
\hline \multirow{2}{*}{ Soil Association } & \multicolumn{4}{|c|}{ Criteria based on the share of soils of different taxa, $\%$} \\
\hline & $\mathrm{CHt}+\mathrm{CHl}$ & CHtk & Mch & additional conditions \\
\hline $\mathrm{CHtCHl}$ & $\geq 75$ & - & - & $\mathrm{CHt}>\mathrm{CHl}$ \\
\hline $\mathrm{CH}$ & $\geq 75$ & - & - & $\mathrm{CHl}>\mathrm{CHt}$ \\
\hline $\mathrm{CHtkCHtCHl}$ & - & $>50$ & - & $\mathrm{CHt}>\mathrm{CHl}$ \\
\hline CHtCHlCHtk & $50-75$ & - & - & $\mathrm{CHt}>\mathrm{CHl}$ and $\mathrm{CHtk}>\mathrm{Mch}$ \\
\hline CHlChtCHtk & $50-75$ & - & - & $\mathrm{CHl}>\mathrm{CHt}$ and $\mathrm{CHtk}>\mathrm{Mch}$ \\
\hline $\mathrm{MchCHtCHl}$ & - & - & $50-75$ & $\mathrm{CHt}>\mathrm{CHl}$ \\
\hline $\mathrm{MchCHlCHt}$ & - & - & $50-75$ & $\mathrm{CHl}>\mathrm{CHt}$ \\
\hline MchCHmCHl & - & - & $50-75$ & $\mathrm{CHm}>\mathrm{CHl}$ \\
\hline Mch & - & - & $>75$ & $\mathrm{CHl}>\mathrm{CHt}$ \\
\hline $\mathrm{CHtCHIMch}$ & $50-75$ & - & - & $\mathrm{CHt}>\mathrm{CHl}$ and $\mathrm{Mch}>\mathrm{CHtk}$ \\
\hline $\mathrm{CH}$ & $50-75$ & - & - & $\mathrm{CHl}>\mathrm{CHt}$ and $\mathrm{Mch}>\mathrm{CHtk}$ \\
\hline
\end{tabular}

humus content is characterized by a low scattering of values within the studied area. Heavy loamy chernozems with a relatively low variation in the humus content are almost ubiquitous. Therefore, the average value of this coefficient calculated according to [37] was taken; for the study area, it is $35 \mathrm{~kg}$ ha $\mathrm{h} /($ ha $\mathrm{mJ} \mathrm{mm}$ ). The soil-protective role of cultivated crops for the crop rotation in relation to the erodibility of naked fallow was set equal to 0.4 for the entire period of agricultural development according to published materials [8, 20].

Note that it seems possible to increase the detail of some input parameters of the erosion model for solving scientific and practical problems. In particular, it is permissible to specify the coefficients of soil loss tolerance and soil-protective role of cultivated crops for individual farms, as well as to take into account the history of crop rotations; The erosion potential of rainfall $x$ can be specified with due account for climatic changes; the configuration of the field infrastructure, shelterbelts, and other reclamation measures can be also taken into account. In this study, the level of detail of the input parameters for digital modeling was chosen in accordance with the level of detail of the input parameters used in traditional mapping in order to compare the results obtained by different methods correctly.

In general, we used a high level of detail of the input parameters. As a rule, modeling of soil erosion for large areas (for large-scale studies and on a smaller scale) is carried out on the basis of digital elevation models obtained using remote sensing data [10, 34, 36]. However, the use of remote sensing data does not yet allow assessing erosion-accumulative processes at the highest level and is significantly inferior to the use of digital elevation models obtained via digitizing large-scale topographic maps [14, 28].

During the field survey of the soil cover, the degree classes for soil erosion were determined according to the classification suggested in [16]. We identified noneroded (soils of watersheds), slightly eroded soils (the thickness of the humus horizon is less than $20 \mathrm{~cm}$ smaller than that in the noneroded soils on the watershed), moderately eroded soil (the thickness of the humus horizon is $20-40 \mathrm{~cm}$ smaller than that on the watershed), and strongly eroded soil (the thickness of the horizon is more than $40 \mathrm{~cm}$ smaller than that on the watershed). For the subsequent analysis, noneroded and slightly eroded soils were combined into one category of soils with the thickness of the humus horizon $20 \mathrm{~cm}$ smaller than that on the watershed in order to apply a unified methodological approach to soil separation based on the thickness of the humus horizon.

A statistical assessment of the correspondence between the erosion rates calculated by the model and the degree classes for soil erosion established at the sampling points was carried out (Fig. 3). The results indicate that the $75 \%$ confidence intervals of different soil categories do not overlap in terms of the erosion degree. Noneroded and slightly eroded soils are characterized by the estimated rates of erosion within the range of $0-6 \mathrm{t} /$ ha per year; moderately eroded soils, 7-15 t/ha per year; and strongly eroded soils, 19$24 \mathrm{t} /$ ha per year. The $95 \%$ confidence intervals of the selected categories of soil erosion intersect, which determines the likelihood of the share of noneroded, slightly eroded, and moderately eroded soils for the calculated erosion rate of $2-18 \mathrm{t} /$ ha per year; and of moderately and strongly eroded soils for the calculated erosion rate of $13-25 \mathrm{t} / \mathrm{ha}$ per year. According to [6], empirical membership functions for the selected categories of soils of different degree classes for soil erosion and calculated rates of erosion were established, which have the following form:

$$
\mu_{\mathrm{E} 0+\mathrm{E} 1}=\exp (-0.05 x)
$$




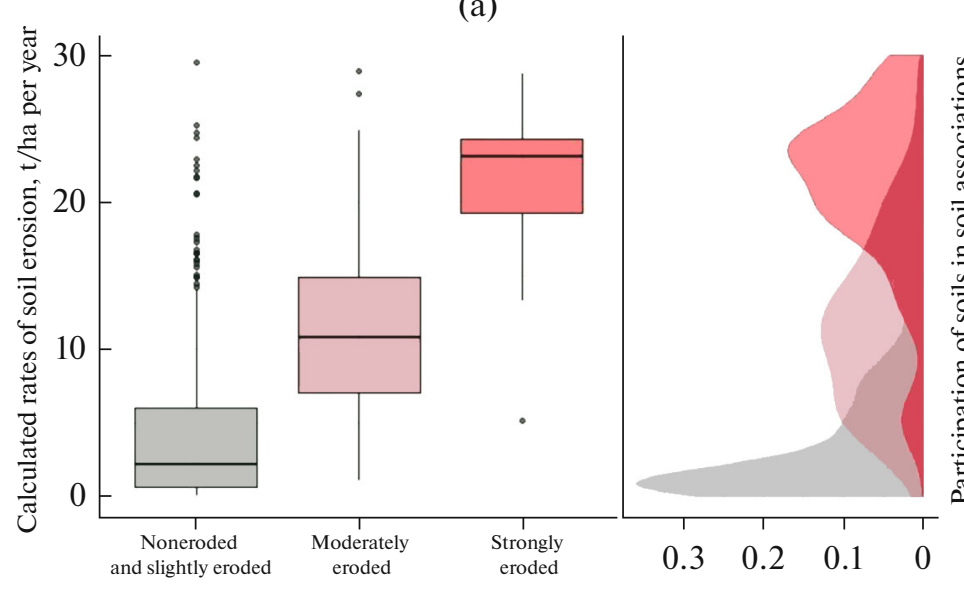

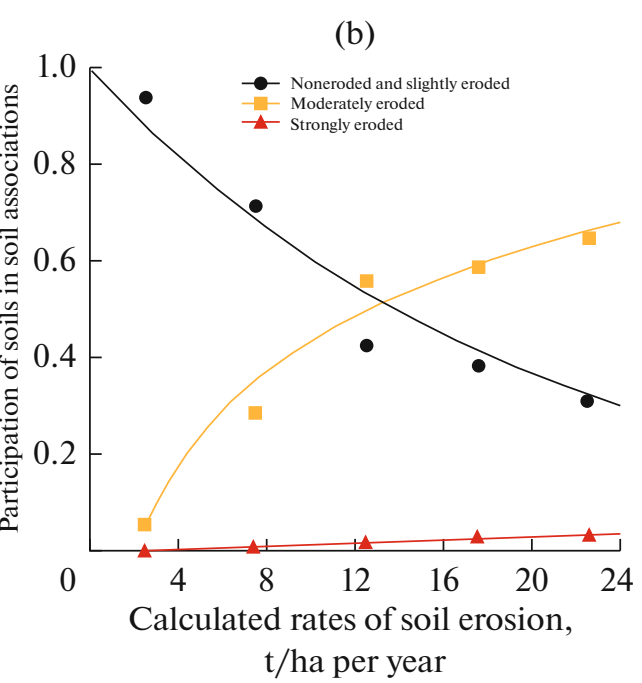

Fig. 3. Comparison of the calculated rates of soil erosion with the degree of soil erosion diagnosed during field studies at sampling points in the form of (a) boxplots and (b) distribution density of the described values and empirically calculated membership functions.

$$
\begin{gathered}
\mu_{\mathrm{E} 2}=-0.2186+0.6532 \log 10(x), \\
\mu_{\mathrm{E} 3}=-0.0066+0.0018 x,
\end{gathered}
$$

where $\mu_{\mathrm{E} 0}+\mathrm{E} 1$ is the probability of participation of noneroded and slightly eroded soils, $\mu_{\mathrm{E} 2}$ is the probability of participation of moderately eroded soils, $\mu_{\mathrm{E} 3}$ is the probability of participation of strongly eroded soils, and $x$ is the estimated rate of soil erosion.

On the basis of the revealed empirical functions and the calculated rates of erosion for each element of the regular grid, the values of the probabilistic share of soil categories with different degree classes for soil erosion were calculated. The database on soil erosion obtained in such way, as well as the database on the proportion of soils of different taxa, can be used for various purposes without distorting the level of detail using GIS.

In order to visualize the obtained information on soil erosion and display it in the form of a map (Fig. 4), the SAs of soil erosion were identified in accordance with the existing standards [12].

\section{RESULTS AND DISCUSSION}

Among the 639 sampled soil sections, the following soils were detected: typical chernozems (320 points), leached chernozems (234 points), typical calcareous chernozems (32 points), solonetzic chernozems (16 points), podzolized chernozems ( 3 points), residual calcareous chernozems ( 1 point), dark gray forest soils (6 points), chernozemic-meadow soils (10 points), and meadow-chernozemic soils (10 points). According to the degree classes for soil erosion, 235 soil pits were assigned to noneroded soils (E0); 230 soil pits, to slightly eroded soils (E1); 157 soil pits, to moderately eroded soils (E2); and 4 soil pits, to strongly eroded soils (E3).

Based on the use of digital soil mapping methods, a model was created that describes the share of soils of various taxa and the degree of their degradation by erosion in each pixel of $20 \times 20 \mathrm{~m}$ for the entire arable land of the Prokhorovskii district, in the form of a table with 1.8 million lines.

A comparison of traditional and digital soil maps shows that, in both cases, the dominant soils are leached and typical chernozems, the areas of which occupy more than $90 \%$ of the territory. At the same time, the areas of leached chernozems on the traditional soil map and in the composition of SAs on the digital map are close to one another: 29000 ha and 30300 ha, respectively (Table 2). The areas of typical chernozems on the traditional soil map and in the composition of SAs on the digital map are also close: 36700 ha and 30900 ha, respectively.

In the southern part of the Prokhorovskii district, on the watershed surface, there are areas with a predominance of podzolized chernozems and dark gray forest soils (Fig. 2). Areas with the participation of typical, residual calcareous, and solonetzic chernozems occur on slopes. The spatial arrangement of typical calcareous chernozems on traditional and digital maps practically coincides; however, the total area occupied by these soils on the traditional and digital maps differs by more than two times: 1900 ha and 4300 ha, respectively.

The greatest differences in the sizes of areas and their spatial confinement are found in soils subjected to periodic overmoistening, particularly, in meadow-chernozemic and chernozemic-meadow soils. According to the data of traditional mapping, the area of meadowchernozemic soils is only $47 \mathrm{ha}$, whereas according to 

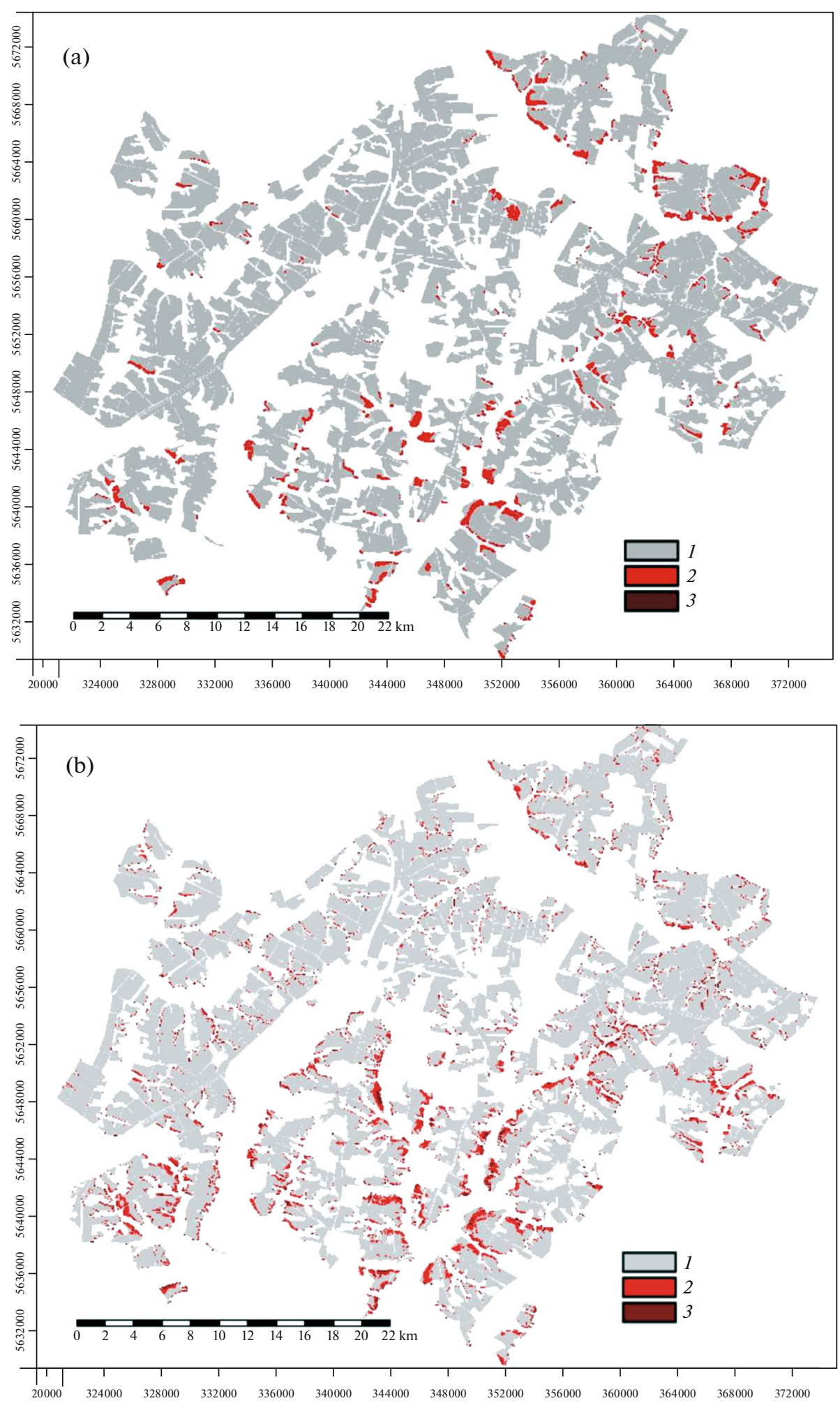

Fig. 4. Maps of erosion of the soil cover of arable territories: (a) traditional map displaying dominant categories $((1)$ noneroded and slightly eroded, (2) moderately eroded, and (3) strongly eroded); (b) digital map displaying SAs ((1) noneroded and slightly eroded soils $>75 \%$; (2) moderately and strongly eroded soils $>50 \%$, moderately eroded soils > strongly eroded soils; and (3) moderately and strongly eroded soils $>50 \%$, strongly eroded soils $>$ moderately eroded soils. 
Table 2. Areas of dominant soils on arable land in Prokhorovskii district (hectares) region (in hectares) according to visual expert and digital mapping methods

\begin{tabular}{l|l|r|r}
\hline Soils of different taxa & \multicolumn{1}{|c|}{ Degree of soil erosion } & $\begin{array}{c}\text { Visual expert method } \\
\text { (by dominant category) }\end{array}$ & $\begin{array}{c}\text { Digital method } \\
\text { (by SA) }\end{array}$ \\
\hline CHt & Noneroded and slightly eroded & 35454 & 25872 \\
& Moderately eroded & 1325 & 4915 \\
$\mathrm{CHl}$ & Strongly eroded & 0 & 128 \\
& Noneroded and slightly eroded & 28369 & 25819 \\
& Moderately eroded & 641 & 4422 \\
$\mathrm{CHtk}$ & Strongly eroded & 0 & 111 \\
& Noneroded and slightly eroded & 1377 & 2695 \\
Mch & Moderately eroded & 545 & 1543 \\
& Strongly eroded & 0 & 61 \\
& Noneroded and slightly eroded & 47 & 1305 \\
& Moderately eroded & 0 & 449 \\
& Strongly eroded & 0 & 13 \\
\hline
\end{tabular}

digital mapping, it reaches 1300 ha. Soil associations with meadow-chernozemic and chernozemic-meadow soils on the digital map are allocated to shallow hollows. On the traditional soil map, such hollows are almost indistinguishable with respect to their soils: the same soils as in the surrounding area are shown within their boundaries: typical chernozems, leached and typical calcareous chernozems, etc. The only massif of the overmoistened soils on the traditional map is shown in the lower part of the slope of northwestern exposure in the southeastern part of the Prokhorovskii district. On the digital map, this area is shown by SAs with a predominance of meadow-chernozemic soils (within hollows) and typical calcareous chernozems on interhollow ridges. The underestimation of the areas of meadow-chernozemic and chernozemicmeadow soils on the traditional visual expert maps was specially noted in [9].

The maps of soil erosion, created by visual expert and digital methods, are largely similar in the spatial position of soil areas with different classes for soil erosion (Fig. 4). This could be expected, because the localization of the areas of eroded soils is mainly controlled by topography, which is taken into account in both traditional and digital mapping. However, delineations of eroded soils on the digital map are smaller and more intricately arranged, though their total area is larger than that on the traditional map.

The areas of differently eroded soils as diagnosed by traditional and digital mapping methods differ significantly (Table 2). According to the visual expert method of mapping, noneroded and slightly eroded soils absolutely predominate and occupy 95.4-96.3\% of the arable land in the Prokhorovskii district. In turn, digital mapping indicates that their percentage is is significantly lower: $82.7 \%$. The discrepancy in the areas of moderately and strongly eroded soils as mapped by different methods is significant and reaches 9000 ha (13\% of the total arable land in Prokhorovskii district).

The discrepancies in the areas of eroded soils obtained by different methods of mapping are important for characterizing the soil cover pattern of the studied territory. The closest indicators were found for typical calcareous chernozems (CHtk); these soils are mainly allocated to the lower parts of slopes, and their formation may be related to erosion processes. According to both mapping methods, the share of moderately and strongly eroded soils reaches about one third of the total area of CHtk (28.4-32.8\% according to the visual expert method and $37.3 \%$ according to the digital method). According to the visual expert method, the share of moderately and strongly eroded soils from the total area of typical $(\mathrm{CHt})$ and leached $(\mathrm{CHl})$ chernozems is $2.2-4.1 \%$; according to the digital method, it is 4-7 times higher and reaches $14.9-16.3 \%$. The largest discrepancies are noted for meadow-chernozemic (Mch) soils: the share of moderately and strongly eroded soils in the total area of these soils is only $0.4 \%$ according to the visual expert method and $26.1 \%$ according to the digital method.

We have performed a visual comparative analysis of the spatial localization of areas with the greatest discrepancy in the degree classes for soil erosion mapped by visual expert and digital methods. Such areas are evenly scattered throughout the entire region and do not create large areas; as a rule, their size is less than 1 ha. In some cases, their area reaches several hectares. An underestimation of the degree of soil degradation by erosion is observed almost everywhere for the visual expert mapping as compared with the digital mapping. At the same time, about 1300 ha occupy areas, where the opposite situation is noted: the traditional map shows moderately and strongly eroded soils 
Table 3. Areas of soils with different degrees of erosion on arable land in Prokhorovskii region (thousand hectares) according to visual expert and digital mapping methods

\begin{tabular}{l|c|c|c}
\hline \multirow{2}{*}{\multicolumn{1}{c}{ Degree of soil erosion }} & \multirow{2}{*}{$\begin{array}{c}\text { Visual expert method, } \\
\text { dominant category }\end{array}$} & dominant category & SA \\
\cline { 3 - 4 } & & 62.1 & 55.7 \\
Noneroded and slightly eroded & 6.2 & 4.3 & 11.3 \\
Moderately eroded & 2.5 & 0.9 & 0.3 \\
Strongly eroded & 0.0 & & \\
\hline
\end{tabular}

(categories 2 and 3 in Fig. 4a), whereas the digital map shows SAs with a predominance of noneroded and slightly eroded soils (category 1 in Fig. 4b). Such areas are concentrated mainly in the northern and western parts of the district; the size of particular delineations reaches several hectares; in some cases, dozens of hectares.

Note that the above analysis was based on a comparison of soil erosion maps obtained by the visual expert method with the identification of dominant soils and by the digital method with the identification of SAs. However, the digital soil cover model makes it possible to operate not only with SAs but also with dominant soil categories. In this case, each pixel corresponds to one dominant soil and one class of erosion. This approach, in particular, is used to check the accuracy of a digital soil cover model, to compare the spatial position of specific soils of different taxa, and for other purposes.

During the transition from SAs to dominant soils of different taxa, slight differences in the area and localization of soil areas were revealed. The areas of prevailing soils (typical and leached chernozems) changed by less than $3 \%$ as a result of generalization, and the areas of meadow-chernozemic soils changed by $13 \%$. Typical calcareous chernozems undergone significant changes; their total area decreased by $40 \%$ as a result of generalization. At the same time, the area of typical calcareous chernozems obtained by the digital method with separation of dominant soil in each pixel was 1800 ha and almost completely corresponded to their area on the traditional map (with mapping dominant soils): 1900 ha. Thus, as a result of generalization, despite significant changes in the area of typical calcareous chernozems, the overall content of the digital soil map did not undergo significant changes, and in part became more consistent with the traditional soil map.

In turn, during the transition from SAs to the dominant categories of soil erosion, a significant decrease in the area of moderately and strongly eroded soils was noted. The most significant changes were observed for the area of moderately eroded soils: in the composition of SAs, they amounted to 11300 ha; after the transition to the dominant category, their area decreased by almost four times to 4300 ha (Table 3 ). Such strong differences are due to the specific arrangement of ele- mentary soil erosional areas, the formation of which is controlled by meso-, micro- and nanotopography. Eroded soils are usually found in combination with noneroded and slightly eroded soils. In the conditions of modeling on a regular grid $20 \times 20 \mathrm{~m}$, SAs may include soils with different erosion classes. When mapping the dominant category, information on the proportion of soils of varying degree classes for erosion in the composition of SA is generalized, which leads to an underestimation of the area of eroded soils as a result of incomplete account for accompanying moderately and strongly eroded soils.

A relationship was revealed between the area of the zones of discrepancy between the degree classes for soil erosion diagnosed by different methods of mapping and the steepness of slopes. On slopes of low steepness, the areas of nonconformity zones are very small (only $2 \%$ of the total area of nonconformity zones at slopes of $0^{\circ}-1^{\circ}$ ); with an increase in the steepness of slopes, they sharply increase $(21 \%$ for slopes of $1^{\circ}-2^{\circ} ; 49 \%$ for slopes of $2^{\circ}-3^{\circ}$, etc.), reaching a maximum on the steepest slopes (up to $89 \%$ for slopes $>5^{\circ}$ ). It is important to note that, as a rule, on slopes of high steepness, the discrepancy is noted towards a higher degree of degradation by erosion mapped by the digital method.

\section{CONCLUSIONS}

On the basis of digital methods of soil mapping, a spatial model has been created for erosion on arable land in the Prokhorovskii district, which reflects the idea of the spatial organization of the soil cover in the forest-steppe zone of the Central Russian Upland. On the obtained digital map, in the direction from the divides to the lower parts of slopes, there is a regular alternation of soil associations $\mathrm{CHICHt}$ to $\mathrm{CHtCHl}$, then to $\mathrm{CHtCHlCHtk}$ and $\mathrm{CHtkCHtCHl}$ with a simultaneous increase in the share of eroded soils. This generally agrees with published data $[18,21]$ and with the map created on the basis of visual expert method.

Comparison of the maps created by visual expert and digital methods did not reveal fundamental differences in the total areas and spatial distribution of soils of different taxa, however, but showed significant differences in mapping the degree of soil degradation by erosion. When mapping soils of different taxa in different ways, the greatest differences were found for the 
areas of soils subjected to periodic overmoistening, i.e., for meadow-chernozemic and chernozemicmeadow soils, which is due to the poor consideration of shallow hollows in the visual expert method of mapping. Nevertheless, the closeness of the results of mapping of different soil taxa by the two methods should be noted, though the provision of the studied area with soil pits is relatively low (on average, 1 soil pit per $110 \mathrm{ha}$ ). The digital map contains more information about the soil cover, since it characterizes the component composition and proportion of soils in each pixel, in contrast to the traditional soil map, which depicts only the dominant category.

Differences in the degree classes for soil erosion shown on the maps are due to both the method of mapping (visual expert and digital) and the content of the mapping information (dominant category or SA). In the case of visual expert mapping, a significant (by three-four times) underestimation of the areas of moderately and strongly eroded soils is noted because of the poor consideration for the factors other than slope steepness in the development of erosion-accumulative processes. With an increase in the steepness of slopes, the discrepancies between the assessments of soil erosion obtained by visual expert and digital mapping methods tend to increase. Also, as a rule, on slopes of greater steepness, the discrepancy is noted towards a higher degree of degradation by erosion on the maps created by the digital mapping method.

A significant decrease in the total area of moderately and strongly eroded soils occurs during the generalization of the content of the maps from SAs to the dominant classed of soil erosion. This is mainly due to the underestimation of the areas of associated moderately and strongly eroded soils in SAs. It should be noted that the mapping of soil cover erosion, as a rule, is traditionally aimed at the development of erosion control measures. From this point of view, information on small areas of moderately and strongly eroded soils locally interspersed in the areas of slightly eroded soils is not required. However, this information for the areas of a regular grid of high resolution (tens of meters) can be important for solving various scientific and applied problems. In particular, it is valuable for precision farming, for detailing the agro-ecological grouping of lands, etc.

In general, it can be noted that digital databases are more informative than traditional maps. The ability to store and process information in the GIS in its original form for each individual element of the regular grid (pixel) enables a more detailed analysis of information about the organization of the soil cover and the degree of soil degradation by erosion. The visualization of information in a graphical form (in the form of maps) leads to its generalization and, therefore, to a distortion of localization and area of soil mapping units and, especially, for units characterizing degree classes for soil erosion.

\section{FUNDING}

This study was supported by the Russian Foundation for Basic Research (project no.18-35-20011); data generalization and mapping were performed within the framework of state assignment no. 0591-2020-0029.

\section{CONFLICT OF INTEREST}

The authors declare that they have no conflict of interest.

\section{REFERENCES}

1. L. D. Balsanova and A. B. Gyninova, "Soil cover pattern on the northern macroslope of the Tsagan-Daban Ridge in the Transbaikal region," Eurasian Soil Sci. 41, 1256-1259 (2008).

2. S. V. Goryachkin, Soil Cover of the North: Structure, Genesis, Ecology, and Evolution (GEOS, Moscow, 2010) [in Russian].

3. V. D. Ivanov and S. N. Bozhko, "The soil cover and soil properties of gully catchments in the Central Chernozemic region," Eurasian Soil Sci. 33, 585-595 (2000).

4. E. A. Zazdravnykh, Candidate's Dissertation in Geography (Belgorod State University, Belgorod, 2017).

5. V. I. Kiryushin, Ecological Principles of Design of Agricultural Landscapes: Manual (Kvadro, St. Petersburg, 2018) [in Russian].

6. D. N. Kozlov, A. P. Zhidkin, and N. I. Lozbenev, "Digital mapping of erosion soil cover structures based on a simulation model of run-off (northern foreststeppe of the Central Russian Upland)," Byull. Pochv. Inst. im. V.V. Dokuchaeva, No. 100, 5-29 (2019).

7. M. S. Kuznetsov and G. P. Glazunov, Erosion and Soil Protection (Moscow State University, Moscow, 1996) [in Russian].

8. G. A. Larionov, Erosion and Deflation of Soils: General Pattern and Quantitative Assessment (Moscow State University, Moscow, 1993) [in Russian].

9. E. A. Levchenko, Candidate's Dissertation in Agriculture (Moscow, 2020).

10. L. F. Litvin, Z. P. Kiryukhina, S. F. Krasnov, and N. G. Dobrovol'skaya, "Dynamics of agricultural soil erosion in European Russia," Eurasian Soil Sc. 50, 1344-1353 (2017).

11. S. V. Lukin, Agroecological State and Productivity of Soils in Belgorod Oblast (Konstanta, Belgorod, 2016) [in Russian].

12. All-Union Instruction on Soil Analysis and Compilation of Large-Scale Soil Maps of Land Use (Kolos, Moscow, 1973) [in Russian].

13. Soil Mapping: Practical Manual, Ed. by B. F. Aparin and G. A. Kasatkina (St. Petersburg State University, St. Petersburg, 2012) [in Russian].

14. Spatio-Temporal Pattern of Modern Processes of NaturalAnthropogenic Erosion in the Russian Plain, V. N. Golosov and O. P. Ermolaeva (Academy of Sciences of Republic of Tatarstan, Kazan, 2019) [in Russian].

15. I. Yu. Savin, "A problem of scale in the modern soil cartography," Byull. Pochv. Inst. im. V.V. Dokuchaeva, No. 97, 5-20 (2019). 
16. V. D. Solovichenko, S. I. Tyutyunov, and G. I. Evarov, Manual for Soil-Erosion Analysis of the Slope Lands of Belgorod Oblast (Otchii Krai, Belgorod, 2014) [in Russian].

17. N. P. Sorokina, Compilation Method of Large-Scale Agroecological Soil Maps (Dokuchaev Soil Science Institute, Moscow, 2006) [in Russian].

18. N. P. Sorokina, "Elementary soil structures in the fields of the Kursk Experimental Station," in LargeScale Cartography of Soils and Its Role in Agriculture of Chernozem Zone (Dokuchaev Soil Science Institute, Moscow, 1976), pp. 155-173.

19. N. P. Sorokina and D. N. Kozlov, "Experience in digital mapping of soil cover patterns," Eurasian Soil Sci. 42, 182-193 (2009).

20. G. P. Surmach, Formation of Relief, Forest-Steppe, Modern Erosion Processes, and Anti-Erosion Measures (Volgograd, 1992) [in Russian].

21. M. I. Fishman, "Chernozemic complexes and their relation with relief in the Central Russian Upland," Pochvovedenie, No. 5, 17-30 (1977).

22. V. M. Fridland, The Structure of Soils Cover (Mysl', Moscow, 1972) [in Russian].

23. N. B. Khitrov and S. V. Loiko, "Soil cover patterns on flat interfluves in the Kamennaya Steppe," Eurasian Soil Sci. 43, 1309-1321 (2010).

24. Ts. Ts. Tsybikdorzhiev, S. O. Khodoeva, and B.-M. N. Gonchikov, "Soil cover patterns and land assessment in the Baikal region of Buryatia using the example of the Kabansk district," Eurasian Soil Sci. 45, 348-356 (2012).

25. Yu. G. Chendev, Evolution of Forest-Steppe Soils of the Central Russian Upland in Holocene (GEOS, Moscow, 2008) [in Russian].

26. J. G. Bockheim and A. N. Gennadiyev, "General state soil maps in the USA," Geoderma 253-254, 78-89 (2015) https://doi.org/10.1016/j.geoderma.2015.04.013

27. A. H. Cambule, D. G. Rossiter, and J. J. Stoorvogel, "A methodology for digital soil mapping in poorly-accessible areas," Geoderma 192 (1), 341-353 (2013). https://doi.org/10.1016/j.geoderma.2012.08.020

28. J. De Vente, J. Poesen, G. Govers, and C. Boix-Fayos, "The implications of data selection for regional erosion and sediment yield modeling," Earth Surf. Process. Landforms 34, 1994-2007 (2009). https://doi.org/10.1002/esp.1884

29. Digital Soil Mapping with Limited Data, Ed. by A. Hartemink, A. McBratney, and L. M. Mendosa-Sanyos (Springer-Verlag, New York, 2008).
30. N. Khitrov, M. Smirnova, N. Lozbenev, E. Levchenko, V. Gribov, D. Kozlov, D. Rukhovich, N. Kalinina, and P. Koroleva, "Soil cover patterns in the forest-steppe and steppe zones of the East-European plain," Soil Sci. Annu. 70 (3), 198-210 (2019). https://doi.org/10.2478/ssa-2019-0018

31. N. Lozbenev, M. Smirnova, M. Bocharnikov, and D. Kozlov, "Digital mapping of habitat for plant communities based on soil functions: a case study in the virgin forest-steppe of Russia," Soil Syst. 19 (3), (2019). https://doi.org/10.3390/soilsystems3010019

32. A. B. McBratney, M. L. M. Santos, and B. Minasny, "On digital soil mapping," Geoderma 117, 3-52 (2003). https://doi.org/10.1016/S0016-7061(03)00223-4

33. M. R. Pahlavan-Rad, F. Khormali, N. Toomanian, C. W. Brungard, F. Kiani, C. B. Komaki, and P. Bogaert, "Legacy soil maps as a covariate in digital soil mapping: a case study from Northern Iran," Geoderma 279, 141-148 (2016). https://doi.org/10.1016/j.geoderma.2016.05.014

34. P. Panagos, P. Borrelli, and K. Meusburger, "A new European slope length and steepness factor (LS-Factor) for modeling soil erosion by water," Geosciences 5 (2), 117-126 (2015). https://doi.org/10.3390/geosciences5020117

35. P. Panagos, P. Borrelli, K. Meusburger, et al., "Global rainfall erosivity assessment based on high-temporal resolution rainfall records," Sci Rep. 7 (1), 4175 (2017). https://doi.org/10.1038/s41598-017-04282-8

36. S. Pena, M. Abreu, M. Magalhães, and N. Cortez, "Water erosion aspects of land degradation neutrality to landscape planning tools at national scale," Geoderma 363, 1-15. 2020). https://doi.org/10.1016/j.geoderma.2019.114093

37. K. Renard, G. Foster, G. Weesies, D. McCool, and D. Yoder, Predicting Soil Erosion by Water: A Guide to Conservation Planning with the Revised Universal Soil Loss Equation (RUSLE), USDA Agriculture Handbook No. 703 (US Department of Agriculture, Washington, DC, 1997).

38. K. van Oost, G. Govers, and P. Desmet, "Evaluating the effects of changes in landscape structure on soil erosion by water and tillage," Landscape Ecol. 15, 577589 (2000). https://doi.org/10.1023/A:1008198215674

39. A. van Rompay, G. Verstraeten, K. van Oost, G. Govers, and J. Poesen, "Modeling mean annual sediment yield using a distributed approach," Earth Surf. Process. Landforms 26 (11), 1221-1236 (2001). https://doi.org/10.1002/esp.275

Translated by D. Konyushkov 